\title{
El mundo animálico como símbolo de marginación social en Faragual y otros cuentos, de Carlos Changmarín
}

\author{
Animalic world as a symbol of social marginalization in \\ Faragual y otros cuentos, by Carlos Changmarín
}

Silvia Quezada Camberos ${ }^{1}$

Fecha de recepción: 23 de agosto de 2020

Fecha de aceptación: 24 de noviembre de 2020

1- Nacionalidad: Mexicana. Grado: Doctorado en Humanidades y Artes. Adscripción: Universidad de Guadalajara. (D) OR-

CID: http://orcid.org/0000-0002-7741-2578. Correo electrónico: silvia.quezada09@gmail.com 


\section{Resumen}

La narrativa de Carlos Changmarín, maestro de la literatura panameña, se ha difundido por el mundo de habla hispana a través de la lectura de Faragual $y$ otros cuentos, una colección de relatos donde historias como "La vaca", "El diario de la Yegua del alcalde", "El tigre", "El gato" y "Galápago en su concha" muestran a los animales como personajes simbólicos de la marginación social. El método retórico resulta el adecuado para mostrar la íntima conexión entre el pensamiento y el enunciado de cada una de las circunstancias a las que orilla la pobreza extrema del entorno campesino. Los cinco relatos, de estirpe realista, se acercan a un naturalismo descarnado, donde las necesidades primarias del hombre entran a cuadro, sin que parezcan ficción.

Palabras clave: literatura panameña, realismo latinoamericano, método retórico, naturalismo, cuento hispanoamericano.

\section{Abstract}

The narrative of Carlos Changmarin, master of Panamanian literature, has spread throughout the Spanish-speaking world through the reading of Faragual $y$ otros cuentos, a collection of stories where some of them such as "La vaca", "El diario de la Yegua del alcalde","El tigre","El gato" or "Galápago en su concha", show animals as symbolic characters of social marginalization. The rhetorical method is adequate to show the intimate connection between the thought and the statement of each one of the circumstances to which the extreme poverty of the peasant environment borders. The five stories, of realistic stock, are close to a stark naturalism, where the primary needs of man enter in to the picture without appearing to be fiction.

Keywords: Panamanian literature, Latin American realism, rhetorical method, naturalism, Spanish American short stories. 


\section{Introducción}

$\mathrm{E}$ principal propósito al que dan inicio estas líneas es abordar la obra cuentística de Carlos Francisco Changmarín (1922-2012), cuya obra, realista por convicción, se colocaría en cualquier lugar de la América Latina en que lo permita la identificación de la biósfera que sirve de escenografía a sus ficciones; las anécdotas de su obra narrativa, a veces crueles, otras desencantadoras, aunque sin variación sensibles a la realidad social de los menos atendidos por las instituciones, podrían suceder en un extremo o en otro del complejo territorio que nos une tanto por la lengua como por los trazos de una historia cultural compleja y bipartita: civilidad/ incivilidad, riqueza/ pobreza, natural/ artificial, posesión/ desposesión, entre tantos otros.

De no ser por el uso enriquecedor de regionalismos propios de Panamá, la narrativa social de Changmarín remite al lector a una circunstancia que rebasa las fronteras nacionales, debido a la proximidad del colonialismo entre las naciones hermanas del Nuevo Mundo, lo que provoca que las vías de acceso para su interpretación se multipliquen. Para estrechar las posibilidades se tomarán como objeto de acercamiento los cuentos contenidos en la antología Faragual y otros cuentos (1978), y de ellos, aquellos en que los animales son los actantes para el devenir de las tramas narrativas.

Faragual y otros cuentos, es una colección de relatos donde historias como "La vaca", "El diario de la Yegua del alcalde", "El tigre", "El gato" y "Galápago en su concha", muestran a los animales como personajes simbólicos de la marginación social. Los relatos, llevan al extremo su estirpe realista, se acercan a un naturalismo descarnado, donde las necesidades primarias del hombre entran a cuadro, sin que parezcan ficción.

Dice Jean Chevalier en su Diccionario de símbolos:

Los animales, que tan a menudo intervienen en los sueños y las artes forman identificaciones parciales al hombre; aspectos, imágenes de su naturaleza compleja; espejos de sus pulsiones profundas, de sus instintos domesticados o salvajes. Cada uno de ellos corresponde a una parte de nosotros mismos, integrada o por integrar en la unidad armonizada de la persona. (1993, p. 104)

Tal y como dice Jean Chevalier, la fauna "interviene" en los sueños y en las artes. En la historia de la literatura, el bestiario comienza desde la antigüedad grecolatina y, conforme cambia la tradición literaria, la representación de los animales va ajustando la carga simbólica que se les atribuye.

En este primer marco de presentación es posible suponer que la exigencia realista se contrapondría con la imaginería, el folklor, el simbolismo o la mística que, según se lee, se atribuye a los animales; habría que recordar que tras los discursos más fantásticos o fabulosos, se pueden rastrear exposiciones de una realidad no ficcional, así mismo, en el apego al régimen de verosimilitud del que pende el realismo no se exime incluir todas las abstracciones que nutren las conductas colectivas. "La visión de las cosas ha oscilado siempre entre dos polos, la objetividad y la subjetividad. La primera podría identificarse con el realismo, y la segunda con el idealismo. La distinción plena entre ambos es la forma de encarar las cosas" (Estrada y Pérez, 1983, p. 287). 
Para lograr el cometido de abordar la realidad por medio de la representación simbólica, alegórica o mítica de los animales que transitan los hábitats de Changmarín, será necesario desentrañar los recursos retóricos de que se sirve el autor en la configuración de estos peculiares seres. A fin de dar orden a las ideas, se ha dividido el presente texto en dos apartados, el primero de ellos contribuye a localizar la propuesta creativa del autor en la corriente literaria del realismo hispanoamericano, con lo cual se logra explicar, en gran medida, la presencia de elementos, valga la contradicción, inexplicables, extraños, fantásticos, mágicos o maravillosos en una corriente literaria que parece repelerlos; en la segunda parte, se lleva a cabo un comentario analítico que mira, con ayuda de las herramientas de aproximación retórica, cómo los animales contribuyen a la formación de un discurso social en los cuentos contenidos en Faragual y otros cuentos, en dicho análisis es que se sustenta la tesis que da título a esta presentación.

La narrativa de Carlos Changmarín es señalada dentro del realismo, corriente reconocida como una tendencia universal; la intención realista en las literaturas regionales fluye por senderos que culminan en localizaciones precisas, es decir, si las sociedades son distintas, la realidad que plasma la literatura también dependerá de ese accidente geográfico. Para hacer más clara esta idea, hay que tener en perspectiva los sucesos precedentes a la implementación del realismo como estética dominante:

El realismo, que se extendió por todas partes presentó distintos rasgos en los diversos países. El francés es un realismo amoral, de desafío de los convencionalismos sociales; el ruso está ligado a un deseo de redención, de búsqueda religiosa y de afán salvador; el español no fue tan descarado como el francés; el inglés-victoriano es mitigado; el hispanoamericano busca el mejoramiento del campo y la ciudad. (Estrada y Pérez, 1983, p. 289)

Parece una mezcla complicada de ingredientes: se trataba de reflejar la realidad local, una realidad que no ha sido, ni parece estar ahora, cercana a estados de bienestar social, la búsqueda de un mejoramiento incluía una dosis de idealismo, evocar las creencias populares, traer a colación ciertos mitos que ensancharan las posibilidades de encontrar recursos positivos, imprimir cierta nostalgia que instara a recordar el efectivo y afectivo carácter de la diversidad identitaria que se había heredado de los antiguos habitantes de América y de las mezclas con los poderosos invasores.

La búsqueda del bienestar se perseguía mediante la presentación de realidades injustas pero diseñadas para poner sobre relieve una conciencia "objetiva" de las circunstancias que no dejaba a un lado el cuidado del lenguaje. Ese registro de los entornos sociales llegó al extremo de marcar los aspectos más oscuros de la existencia, sin maquillajes engañosos; como hijo legítimo del realismo, el naturalismo reclamó su posición en sociedades en las que las condiciones le fueron, por desgracia, favorecedoras.

Entre realismo y naturalismo media un sistema de representación con sutiles distinciones: "Mientras el realista cuida su estilo busca la expresión exacta de lo que quiere decir, al naturalista le interesa presentar verdaderos "trozos de vida", solazándose en los aspectos crueles de esta" (Estrada y Pérez, 1983, p. 287), hay un notorio grado de exposición de la realidad en cuya base está la brutalidad.

El estilo realista, por lo tanto, puede entenderse como una tendencia común en diferentes latitudes, pero única y diferenciadora de cada una de ellas, en sus notas distintivas. Es dentro de estos parámetros que se coloca a la prosa de Changmarín, sus historias presentan una realidad común y por lo general 
desalentadora de los pueblos latinoamericanos, y en su propio apego a esa calca estética del entorno, se convierte en un vocero de los pormenores panameños.

Esta no es la única distinción que se debe destacar: las estrategias narrativas que han servido al realismo son amplias, el registro puede oscilar desde la simulación de una escritura periodística, como lo ejecutaron algunos de los escritores de la Revolución Mexicana, a extremos que al ojo lego podrían parecerles distantes de la realidad objetiva. La cualidad subjetiva de la idiosincrasia latinoamericana, en cuya base se encuentran registros de las creencias, los mitos, la cosmogonía, las supersticiones y hasta el sistema de valores morales de las culturas originarias es lo que pone en confrontación la objetividad y la subjetividad de los recursos de la realidad. Para el escritor heredero de estas tradiciones multiculturales:

El deber testimonial no le impide un fabuloso ejercicio del poder de la ficción, poner en eficaz funcionamiento la pujanza épica y la protección mitológica. De modo paradójico, esta narrativa realista gesta una mitología de Nuevo Mundo, alimenta el legendario sueño de los pueblos de América. Recoge relatos de vida y los enriquece con cuentos y creencias de carácter folklórico, recrea el arquetipo del aventurero y del sojuzgado, del pionero y del atrasado, del fronterizo y del enraizado. Recrea en todos sus aspectos la relación de los hombres entre sí y con el medio natural y social. (Yurkievich, 2010, p. 176)

Los relatos de Changmarín se ciñen también a esta dinámica dual en la que la realidad se nutre de ficciones, en la que lo objetivo no puede eludir las explicaciones empíricas que desdibujan los límites de lo humano y sobrehumano porque la única mediación entre ambos es una indómita naturaleza. Esta cualidad ubica al panameño en una cajonera específica, siguiendo a Yurkievich habría dos distinciones más:

Dos parejas de tendencias anatómicas se distinguen nítidamente, por un lado, la narrativa de la tierra, de tierra adentro, de ambiente rural, de carácter regional o indigenista... Por otro lado, como antinomia, se desarrolla la narrativa urbana, la idea de la ciudad caleidoscópica, la del mundo cambiante, agitado, inquietante, revuelto, la de los advenedizos y la de los fracasados ... El otro binomio de narrativas divergentes contrapone la tendencia social a la tendencia psicológica. La social quiere presentar al ser colectivo a través de las alternativas de personajes prototípicos, o directamente pone en acción -o sea, en situación y reacción comunes- a las masas populares. La tendencia psicológica es introspectiva; individualiza y singulariza a sus tortuosos, dubitativos personajes, y juega con la alternancia y hasta la confusión entre zambullidas en el turbio universo de la urbe y en los turbulentos trasfondos de la psique. (Yurkievich, 2010, p. 176-177)

Estas cuatro gavetas no son herméticas, es decir que, dado el carácter de los documentos que las componen habrá cruces de caminos. Las narraciones que conforman Faragual y otros cuentos, estarían en un grupo que conjunta lo rural y social, ubicadas en los ambientes naturales de Panamá.

De manera involuntaria el autor que nos ocupa secunda su categoría, en "Seis Madres", cuento en tres partes incluido en Faragual y otros cuentos, donde se leen las siguientes líneas, singulares por su carácter metaliterario: "no soy un profesional de la literatura, sino uno más empujado por la realidad social, fun- 
damentalmente en las batallas por los pobres, y decir tanto como que tengo tiempo para quemarme las pestañas en el ejercicio y la maroma del lenguaje y del estilo, sería fantasioso de mi parte" (1947/1978, p. 64). La cita no sólo constata, sino que nos conduce a la reflexión de las cualidades específicas de su prosa, si bien es cierto que la intención social lo agrupa en una selección que suma un vasto número de escritores y obras continentales, aspecto en que escritor y lectores consentimos, no es posible darle la razón en cuanto a la declaración que implica una ejecución despreocupada del lenguaje y del estilo.

\section{Sobre Faragual y otros cuentos}

Faragual y otros cuentos no es una obra aislada en el quehacer de Carlos Changmarín, poeta, ensayista, músico, pintor, periodista, profesor y luchador social; en la sumatoria de sus publicaciones se congregan casi siete décadas de trabajo artístico con la palabra, desde 1947 hasta el 2005, Changmarín suma 19 publicaciones que incluyen cuento, poesía, novela, la biografía de Victoriano Lorenzo y algunos libros de décimas.

Algunos de sus libros han sido traducidos a diferentes lenguas: búlgaro, ruso, francés y chino, además de obtener reconocimientos en certámenes literarios, la Universidad de Panamá le ha reconocido con el Premio Universidad en el 2002. En 2006 recibió la Condecoración “Rogelio Sinán”, otorgada por el mérito de la obra literaria de toda una vida. El Gobierno de Panamá lo reconoció con la Orden Nacional General Omar Torrijos Herrera por su trayectoria como luchador social y ejemplo de constancia en la búsqueda de una sociedad con justicia social, equidad, libertad e independencia.

En 2008, el Instituto Nacional de Cultura (INAC) creó el Premio Nacional de Literatura Infantil Carlos Francisco Changmarín, cuyo principal interés es la promoción y difusión de los autores panameños que escriben para los niños. Por su calidad y profundidad discursiva, su obra Faragual y otros cuentos es sugerida como lectura básica por las instituciones educativas de educación media y universitaria. La constante en esta extensa actividad artística es el interés por la denuncia implícita en cada una de sus publicaciones.

Su obra más reconocida, aunque poco abordada por especialistas y por lectores foráneos es, como podrá suponerse, Faragual y otros cuentos, edición que reúne casi una docena de cuentos del autor escritos a lo largo de más de dos décadas. Según se lee en la nota de los editores:

Se publican aquí cuatro cuentos del libro "Faragual, Segundo premio del Concurso Nacional de Literatura” Ricardo Miró, de 1959; “Seis Madres”, premio nacional de 1947; "El Hombre de Catival”, del libro de relatos de la cárcel: "Mansión de la Bruma" y otros cuentos, para ofrecer una muestra variada de la obra del autor, a través de distintas épocas. (1978, s/p)

Pese a la intención de destacar la cualidad diacrónica, no es notoria una diferencia en la calidad de las narraciones, todas ellas coinciden en estilo, su longitud es promedio (diez cuartillas), y mantienen rasgos estilísticos semejantes, lo que podría señalarse como una cualidad del autor en el oficio de la escritura.

El acercamiento analítico a esta peculiar muestra de la literatura regionalista de Panamá parte del rastreo al ambiente animálico que vive y da vida al universo campesino que hace posible Changmarín, en este acercamiento tomará una metodología ecléctica, surgida de los elementos propios de los textos trabajados. Aunque hay una vía de acercamiento inmediata en los cuentos cuyos títulos señalan en directo a algunas especies vivas, y serán esas historias las que precisen de mayor atención, hay también 
otras estrategias narrativas que usan a los animales con propósitos variados, de ellas las que destacan son: 1) la mención a animales como parte del registro léxico regionalista, 2) los animales son parte de las descripciones que contribuyen al posicionamiento cronotópico. Los títulos de los cuentos, claramente temáticos de acuerdo con la terminología de Gérard Genette, se refieren a personajes simbólicos, porque no abordan a una vaca o a un tigre como tema central, sino que es la función de estos animales lo que importa: "Un lugar /tardío o no), un objeto (simbólico o no), un leitmotiv, un personaje incluso central, no son propiamente dichos temas, sino elementos del universo diegético de las obras que titulan" (p.72-73).

En los cuentos aparecen arroceros, cacicongos, gallinazos o gallotes, pájaros brujeros, o robiblancas adornan los paisajes abiertos ya en piso, ya en los limpios cielos del campo. También hay cuchos, como les dicen a los perros, galápagos, michos o gatos y macanas, palabra con la que se nombra a una especie de pez de río. El chivato o la culebrona, por el contrario, no refieren a animales, se nombra así al diablo, cuya representación tradicional toma forma de venado o de chivo y a las deudas. Para ejemplificar el segundo caso, cuyos ejemplos podrían abarcar páginas completas, bastará con abrir las primeras páginas de la edición:

En ese mar de yerbas el ganado pace entretenidamente. Se multiplica el bramido.

Muge dolorosamente el viejo toro y en el horizonte crepuscular responden los terneros, cuyas siluetas graciosas son salpicadas de reflejos cegadores. El pajonal, estremeciéndose, doblega las cuchillas lanceoladas de sus hojas hasta rastrear el suelo. (Changmarín, 1959/1978, p. 5)

"Faragual" podría representar un caso peculiar, pues, si bien no se nombra a un animal, el faragual es el campo poblado de faragua, la hierba de que se alimenta el ganado. Lo que constituye un campo semántico común. Es predecible, pues, que se mencionarán los mamíferos de cría, aun así, el párrafo anterior ilustra la manera peculiar de describir los entornos rurales, en donde la flora y la fauna son tanto parte del espacio diegético como recursos que determinan la condición de los personajes, es decir, que las acciones (significativas o accesorias) de estos, estarán determinadas por su quehacer o el deber con respecto al manejo de sus recursos naturales, ya sean animales o vegetales.

En "La tempestad" el registro de la flora y de los sembradíos de consumo es mucho más rico, aun así, es posible rastrear a los animales como parte del entorno de los personajes, "Aquella tradición de las lechonas asadas, de los dulces, del caballo, se derrumbaba ante el empuje de la miseria y de los cambios operados en las regiones más remotas del país" (1978, p. 33). El personaje principal rememora un pasado de abundancia; la abundancia, en el medio rural, está vinculada con las posesiones, pero a diferencia de entornos menos rústicos, la riqueza no se mide en cuanto a poder adquisitivo, no depende de la moneda, sino de bienes de consumo y de ayuda a la labor, esto es, en la posesión de crías de ganado y animales de granja y de tierras fértiles para la siembra.

En este cuento se sugiere que, en el bienestar y la abundancia, los campesinos pueden tener un caballo, criar cerdos y comer de su carne tierna. El caballo, mencionado en este relato de forma breve, es un animal al que, de común, se le considera una posesión que otorga poder y prestigio a su amo: los guerreros de antiguas batallas, los hacendados, los conquistadores de alto rango tenían entre sus más preciadas posesiones un caballo que facilitaba sus rudas actividades y era, además, un compañero al que se le debía atención, respeto y cuidado, él a cambio, dota a su amo de "altura", fuerza y rango. 
En "Seis madres", a lo largo del primer párrafo se lee: "Al caminar mi caballo se humedece y los zapatos se empapan en los charcos de agua. La gente observa y habla, tal vez de mí. La lluvia sigue. Yo cruzo la calle de regreso de la inútil búsqueda de trabajo; a mí me empuja el hambre, a mis vecinos, los detiene, en la esquina, también el hambre”. (1978, p. 63). El hombre se ha bajado del caballo y con ello ha perdido todos los privilegios que le otorga la posesión y el uso de su animal, pese a conservar el impulso de la movilidad, se equipara, en tierra a sus demás congéneres, comunes por el hambre.

En su misma travesía, el personaje cuenta: "Al regresar paso por el mercado, por si las moscas ... pero ya no queda más que falda y huesos de cabeza; compro los huesos" (1978, p. 68). Si bien tiene poder adquisitivo, si bien le queda un poco de estatus, no tiene lo suficiente como para marcar su distancia con la precariedad, en vez de falda, carne entera, se conforma con los huesos. La dieta es, por tanto, un indicio de bienestar, si la dieta incluye animales hay riqueza, de no ser así, el sujeto se encuentra en precariedad.

Esta clase de ejemplos son abundantes, en ellos, los animales no figuran como determinantes de las acciones narrativas expuestas en la totalidad del relato, lo que se narra es otra cosa, sin embargo, acentúan los discursos: "Comer comida. Carne si pudiera ser; carne seca, salada, ensartada en un chuzo de rama de guayabo, que le da su gusto" (1978, p. 123). Como puede leerse, la comida es sinónimo de carne, lo demás no obtiene esta categoría. Por otro lado, los discursos son la materia común en la serie de relatos que componen la antología sujeta a análisis, lo que hay de común entre los relatos que involucran a los animales como actantes primarios de la acción y aquellos que los evocan de forma secundaria es que, la marginación, aspecto discursivo que se pretende destacar, tendrá como indicio de su construcción, una estrecha relación con el mundo animal.

La lista de los cuentos que de modo explícito hacen referencia a los animales desde su presentación son: "La vaca", "El diario de la Yegua del alcalde", "El tigre", "El gato" y "Galápago en su concha”; además, "Faragual", se ha dicho, puede ser considerado dentro del grupo de textos de interés, dadas sus connotaciones. Con este último, la mención al mundo animálico comprende la mitad de las narraciones incluidas en la antología, sin ahondar en el contenido, ya se observa la fuerte injerencia de los no humanos para referir las peripecias de los seres humanos.

En orden de aparición se ha de seleccionar "Faragual" para iniciar una exposición más enfocada. En este cuento, la descripción como estrategia narrativa es predominante, pero no es una escueta presentación de imágenes, para describir, la instancia narrativa desborda en su presentación retórica, véase por ejemplo la descripción de los terrenos usados para la faragua:

Es la faragua florecida de las grandes haciendas de ganado; recortada contra un cielo maravilloso. Cuando la estación seca avanza, entonces la faragua, reina de las yerbas, deja caer silenciosamente la semilla. Son pequeños y delgados estambres de color oscuro, que se mueven como mi pueblo de hormigas. Van cayendo a la pata del matojo. Al mediodía, con el calor, caminan, andan como animaluchos de un lado a otro. Más tarde serán recogidos por los peones, para ser guardados en sacos y regados a su tiempo, en nuevas superficies, donde restallarán y millones de hojas nuevas poblarán las distancias de yerbas y más yerbas que han de servir para el ganado. (p. 6) 
Si bien es cierto que la adjetivación predomina, la prosopopeya domina el párrafo, el faragual está dotado de cualidades animadas, pero no le anima atribuyéndole rasgos de personificación, sino de animalización; por analogía se le equipara a un hormiguero, sobra hablar de la simbología de estos insectos: trabajadores, comunales, prósperos, dadores de vida; las hormigas por su parte, se comparan con un pueblo "mi pueblo" nombra el narrador. En la descripción intervienen, entonces, los hombres que trabajan la faragua, el ganado que es el beneficiario y la faragua viva, animada.

La presentación del conflicto es también expuesta mediante la descripción del faragual:

Pero la faragua no sólo es alimenticia, sino temible.

Aquellas rucias manos de los pobres labradores, que echaron la menuda semilla en la tierra, iban, a la vez, cercando fatalmente su existencia de puñales que un día degollarían sus esperanzas humanas. Muy pronto, con el reventar de la semilla, quedaban encercados de potreros. Y la faragua volaba con el viento poblando aquí o allá, mordiendo la buena parcela; castigándola vorazmente; apretando su arcilla; aniquilando su negro humus; succionando su nitrógeno; en fin, devastando, porque allí en donde el faragual hincaba sus raíces, jamás solía levantar otra verdura. (p. 6)

A la descripción se le atribuye un poder de acción: morder, castigar, apretar, aniquilar, succionar, devastar. Se le dota de poder, ese poder es ejercido no sobre los animales, sino sobre los hombres. En oposición, los beneficiarios serán siempre los animales, el ganado. La faragua es la instancia poseedora de atributos de destinador, da bien y lo quita, favorece el ganado y perjudica al hombre: la lucha está entre el hombre que vive de la tierra y el ganado que se alimenta de ella.

En medio de esta exposición de poder está don Julio. Ganadero. La anécdota de la historia es, grosso modo, la siguiente: Los campesinos entablan una batalla legal para contrarrestar el robo de tierras que ya era acción común en el sistema institucional. De manera poco común, sorprendente, el colectivo gana la batalla ante los tribunales. Los campesinos vencieron a Don Julio. Para referir dicha disputa el narrador afirma: "Pelear en las oficinas con Don Julio era "pelea de tigre con chivo amarrado" (p. 9). En un juego metonímico animal y humano se unifican.

Mientras el villano deseaba incrementar su ganado, los campesinos pelean la tierra para sembrar alimentos. Aunque ganaron la batalla legal, los victoriosos perdieron: Don Julio, en venganza, esparció semilla de faragua por los campos de los sembradores, la faragua consumió todo, evitó la siembra. La urbe molesta asesina al ganadero. Entre el muerto y el desposeído hay sólo un ganador: el ganado.

El cuento culmina con los versos:
Adelante, la vaca;
atrás, la vaca;
arriba el cielo
dios y la virgen,
y abajo don Julio. 
El ganado, en este relato, es parte del sistema de poder, aunque a don Julio, en su momento de partida no le fuera útil su posesión privilegiada "Ni todo el ganado de los famosos potreros, ni los miles de billetes de los bancos, ni los alcaldes, diputados, administradores de tierras, ni el presidente de la república, ni el arzobispo servían en esos lamentables momentos para nada" (p. 15). Arguye el narrador. La sentencia agrupa el sistema de poder que funciona como oponente de los pobres, de los campesinos, en él se encuentran todas las instancias de administración social, cuyo poder tangible se localiza en dos bienes materiales: el ganado y el dinero. En síntesis, en "Faragual", los animales sirven al relato para: describir, por comparación, como locuciones adjetivas, además, en otro nivel discursivo, los animales de crianza son representantes del poder.

\section{1. "La vaca"}

El siguiente cuento en orden de edición es "La vaca" a diferencia del anterior se apela a un animal de forma directa y es ella, la vaca, la protagonista de la historia. El suceso narrado carece de la intensidad de fuerzas opuestas, la vaca sube a la cima de un peñasco porque ahí encuentra la frescura al pie de tierra. Los habitantes del pueblo cercano emprenden una odisea para rescatarla y regresarla a piso firme.

La vaca se presenta como un animal al que se le atribuyen capacidades que estarían fuera de proporción, se le humaniza; estando en la cima, desesperada, hambrienta y lastimada, sin poder bajar, brama de dolor, un becerro que está en la parte baja brama con ella: "Y esa dura noche se pasaron las dos almas bestiales rajeando un rosario en donde cada letanía acuchillaba de pena a la pobre humanidad de campesinos. Pocos lograron dormir, porque sentían ganas de bramar desde lo más recóndito de sus nobles y mansos corazones" (p. 24). El párrafo anterior ejemplifica la atribución antitética de accionares, mientras los animales rezan, los campesinos desean bramar.

En la simpleza de la historia y su conflicto hay una intención moralizante. El espacio principal de la acción, la parte más alta de tierra está cargada de una mística particular:

Desde todos los contornos y vecinos horizontes se divisaba la roca. Tenía sus leyendas entre la gente del campo: se dijo, que nadie había subido hasta allá; que los norteamericanos anduvieron clavando señales por los picos más altos del Istmo, para sus bases militares, pero que no habían podido colocar una bandera suya en la peña del cerro. Se hablaba de duendes, o de antiguos indios que moraban en sus alturas y por lo tanto, los campesinos sentían temor de trepar tan alto. No había necesidad de aventuras. (p. 19)

Sin embargo, el temor del pueblo se vence por los más jóvenes, quienes suben a la montaña motivados por un impulso colectivo de humanidad, a su vez, reforzado por la figura humanizada de la vaca. El mayor bien está en la comunidad: "Era más fuerte el poder de los jóvenes campesinos, el profundo sentido de humanidad de sus corazones. Nacía una nueva mañana, aunque jamás la vaca pudiera percibirla, porque yacía muda y ciega" (p. 27).

Sin el impulso colectivo la situación sería otra, como en el cuento "El diario de la Yegua del alcalde" en el que la yegua no es propiedad del alcalde, aunque sí es su jurisdicción, por decirlo de algún modo”. 
Entre "La vaca" y esta otra narración hay correlatos que fortalecen las impresiones sobre la representación del mundo marginal, en ambos casos, hembras animales son las protagonistas mediante las cuales es posible destejer los discursos.

La diferencia en la representación de los animales puede tratarse como una gradación en la que, en un primer nivel estaría la llana descripción de los animales que contribuyen con la creación del paisaje, casi todos ellos aves, insectos y perros, en un segundo nivel estarían los animales que se perciben como de uso humano, que contribuyen con la labor, ya como alimentos, ya como bestias de trabajo, ellos ayudan a la representación de los personajes y de la sociedad; en otro nivel, un nivel en el que la intensidad de lo animálico se pervierte hasta un grado extremo estarían los procesos de humanización de los no humanos, y, aunque hasta ahora no se haya visto el caso, más adelante se refiere el proceso de animalización del ser, que puede darse cuando se desprovee al personaje humano de las virtudes que lo separan de los animales, pero también, como se verá, mutando al ser en espécimen animal.

\section{2. "El diario de la Yegua del alcalde"}

Así, mientras en "La vaca" el animal es humanizado cuando se le dota de capacidades humanas, en "El diario de la Yegua del alcalde" la línea que separa al hombre de la bestia queda suspendida casi en su totalidad. La yegua, personaje principal habla en primera persona contando su propia historia. Ha sido abandonada a las afueras de la alcaldía del pueblo en espera de que se resuelva qué hacer con ella dado que, al morir su amo, no hay a quién o para qué pueda ser útil.

En la vida de la yegua intervienen dos tipos de personajes: por un lado está su viejo amo, hombre de campo: “¿Qué buen hombre aquel! ... Era un campesino luchador, no un juez almidonado” (p. 84). Portador de grandes virtudes, por luchador y también por campesino (recuérdese la estrategia de remitir a las virtudes de uno como ejemplares de su gremio); en oposición está todo el sistema institucional encabezado por el juez, pero al que se adscriben otro: "al juez, al alcalde, al gobernador, al capitán, a las beatas, al cura burlador, a los torturadores, a los emperfumados de la plaza mayor y a los ricachos de la "Calle Real" ¡santo dios!” (p. 92). A quienes se les adjudican los defectos humanos: inmorales, prepotentes, indolentes, soberbios, ostentan el poder que se ejecuta con crueldad sobre sus oponentes.

Aquí un ejemplo de cómo tal poder se acompaña de un ego que supera los límites morales:

Allí vuelve a asomar su hocico "mi capitán".

Bueno, frente a mí es otra cosa, pobre yegua sin respaldo económico, social o político, ¡cómo me grita!; Entonces sí es valiente. No ese valor mío de yegua desamparada que soporte esta tortura, sino la prepotencia de quién, subido sobre sus botas, y armado hasta los dientes, cree verdaderamente que su base es inconmovible, su sistema invulnerable, eterno. El valor del tigre frente al chivo amarrado. (p.84)

Como puede observarse, se pone en entredicho el sistema civil; el escalafón social se determina por el poder económico, la jerarquía y el poder político, instancias de poder que discriminan y al hacerlo echan a andar el sistema de marginación en el que por debajo de sus intereses se encuentran los campesinos y, la yegua. 
La prosopopeya concretada con la humanización del animal no es el único fenómeno animálico, si bien hay un escalafón del poder la jerarquía tiene una línea paralela inversa, en la que se distingue que a mayor poder, habrá menor calidad humana, aquellos que se encuentran en la cima de la primera tabla de clasificación, pierden a tal grado su responsabilidad humana que se bestializan, van tornándose en animales no humanos, por ejemplo, en el enunciado siguiente la yegua habla del juez: "Y dijo que no tengo ni un fierro que me distinga ¡Cierto! El sí tiene uno bien marcado, para diferenciarse del resto de animales que le rodean. ¡Fierro negro en su alma de zorra! ¡Putrefacto!” (p. 82). El impartidor de justicia no es más que un animal, animalizado dos veces pues se le atribuye un alma de zorra: traicionera, escurridiza, oportunista, según su simbología.

El sistema de escalafón de los animales funciona de otra manera, a la cabeza de ellos se localizan los que tienen cierta utilidad para facilitar las labores humanas, en ello radica su valor, la propia instancia narrativa se posiciona en este medidor intangible:

Soy útil: cargo leña, puedo hasta moler en un trapiche. Todo depende de que me den buen pasto. ¿Por qué dicen que no valgo nada? ¿En razón de qué consideraciones me evalúan? Comprendo que los patrones pueden poner un precio a una mercancía por debajo de su verdadero valor, magia de los mercaderes ... . Y tal vez sea posible un grado de comparación entre los valores que representamos el juez y yo, no comprendo mucho de las relaciones humanas, ni de economía política. Pero hay una cuestión de ética: yo no me estoy vendiendo. (p. 82)

Es verdad que destaca con mayor claridad la comparación entre el juez y la narradora, pues se sobreentiende que ambos están sujetos a un escalafón que, según la yegua podría compararse, por lo menos en el mundo que habitan estos personajes, pero, en efecto, se distinguen los medidores, la vara no es la misma. La yegua se adjudica un valor de uso y un valor económico: producción y capital, entre ellos media la ética, que sería un valor humano que, en este caso, sólo ostenta el animal. Vaya contradicción.

Con este marco de presentación "El diario de la Yegua del alcalde" podría ser un cuento ejemplar para observar la marginación social, es quizá el más directo al exponer el asunto, al mismo tiempo, es también significativo para observar la función que desempeñan los animales en la prosa narrativa de Changmarín; en el conjunto de la obra los animales desarrollan una gran variedad de funciones estilísticas, narrativas y discursivas; pero en este cuento en particular, sólo es posible comprender la marginación por medio de su protagonista, las interrelaciones son más claras que las sutilezas que se deben observar en otras historias.

Con la mirada aun puesta sobre la lectura de "El diario de la Yegua..." vale la pena hacer un paréntesis para puntualizar una cualidad que sólo se ha mencionado con brevedad, la anotación puntual se sintetiza en la siguiente idea: la comunidad se convierte en un poderoso eje transversal en los relatos de Changmarín. Hasta ahora se han expuesto narraciones en las que el colectivo campesino es dotado de atributos unitarios, en una especie de intrincada sinécdoque en la que los campesinos en un actuar solitario portan atributos que le son comunes a la colectividad, y viceversa, en el extremo opuesto, el brazo opresor está representado por un grupo de actores que encabezan a las instituciones de gobierno, de la iglesia y de la clase social. No es una casualidad que el espacio de la historia sea la plaza pública, sitio donde se concentra la vida pública, la cual de acuerdo con M. Bajtín es: "Un cronotopo remarcable, donde todas las ins- 
tancias superiores -desde el estado, hasta la verdad- [están] presentados y representados concretamente, [están] visiblemente presentes". (p.283)

La yegua humanizada, o su amo, el narrador de "Faragual" son ejemplos que marcan al colectivo de los campesinos oprimidos. El cura, el juez, o don Julio son representantes del poder opresor contenido en las instituciones del estado, la iglesia, la milicia o la propia sociedad civil, un ejemplo más de este aspecto de la discriminación se puede observar en el siguiente relato.

\section{3. "El tigre”}

En "El tigre" el felino que da nombre a la historia no es uno de los actantes que motiva las fuerzas de oposición, porque se apela a un animal. Este animal atemoriza al pueblo y pone en peligro los bienes de la gente. Quien tiene el poder de aniquilarlo es Tranquilino. El anciano cazador, por su parte, humilde de herencia, es uno de los tantos afectados por la avaricia de Apolonio Nepomuceno Quintero Díaz, Don Quinterón, “Tío Tigre” según le apodaban:

"Tío Tigre" era de temer por el dinero, su influencia y su pasado. Pero también por su gran tamaño, de donde le venía el sobrenombre de Quinterón; apodo que sí le gustaba. En realidad, era el padrote de la familia y el cacique del distrito. Se había quedado con las mejores tierras, y se contaba, que cuando un primo lo quiso parar en el camino de sus atracos, "Tío Tigre" lo aguaitó en una curva del camino real y le atajó el resuello. (p. 97)

Los recursos con que se gesta el símil entre la bestia que asecha a la comarca y el hombre que atemoriza no son fáciles de reseñar, pero son evidentes, el único vínculo entre los dos referentes es el apelativo. Es una manera diferente de presentar aquel juego metonímico en el que los atributos y accidentes de uno se traslapan al otro, y viceversa.

El problema del personaje principal es de carácter moral, el conflicto en términos narrativos es de índole distinta, entre el poseedor y el desposeído, entre el rico y el pobre. Tranquilino es un individuo que padece los mismos abusos que todos aquellos de su misma condición; El Tigre, en contraposición, es el representante del poder hegemónico, es también alcalde, se hace acompañar por subalternos con las mismas pulsiones: "Don Apolonio es Don Apolonio ... y haz de saber que los que, como tú, aquí en la tierra, son los últimos, cuando mueran serán los primeros, allá en el cielo” (p.100) aconseja el cura.

Es estricto decir que a unos y a otros interesa el aniquilamiento del depredador, del asesino animal, los ricos y los pobres desean quitar este obstáculo amenazante del camino, el conflicto de Tranquilino radica en la duda sobre si debe aniquilar a la fiera o asistir a una reunión a la que ha sido invitado bajo coerción. Después de cavilar toda la noche, Tranquilino se decide: "Al fin, tomó la escopeta, su machete, llamó a "Cucho" y se fue, entre claro y oscuro, por el potrero, a cazar el tigre" (p. 106). No es casualidad que el texto culmine con un error sintáctico, las opciones correctas, adecuadas, podrían ser: al tigre, contrayendo preposición y artículo, o bien, a El tigre, respetando la mayúscula que indica el uso de un apodo, en el primer caso quedaría claro que el cazador tendrá por presa el felino, en el segundo, al hombre. 
El final abierto concluye el juego narrativo puesto en marcha con la comparación. El lector tendrá que argüir cuál de los dos casos acierta en la decisión del empobrecido hombre de campo.

Entre la imagen del feroz animal salvaje, indomable, temible y la descripción del carácter del felino protagonista de "El gato" hay observaciones interesantes. Aunque uno de los animales es en proporción mayor que el otro y el carácter salvaje de uno y doméstico del otro constituyen cualidades diferenciadoras, la disparidad también puede ser atendida por su conexión con otros elementos en sus respectivos relatos y puestos en comparación. La opción que se propone ahora es la de mirar los espacios en que estos sujetos se desenvuelven. Desde este punto de vista destacan otros aspectos que abonan a la comprensión del mundo animálico en la prosa de Changmarín.

En principio de cuentas, los animales se localizan en entornos cargados con marcos de referencias: animales y espacios están vinculados, son dependientes, sus cualidades referenciales y, en este caso, sus descripciones, comparten campos semánticos que desdibujan sus contornos. Se trata, entonces, de dos aspectos distintos del relato pero, en su calidad de complementos, entretejen sus atributos. Una de las formas en las que se superponen los distintos recursos narrativos se da cuando las cualidades atribuidas a los animales contienen referentes semánticos que pueden trasladarse a las cualidades de los escenarios, o viceversa.

\section{4. "E1 gato"}

Un claro ejemplo de lo que se intenta exponer se localiza en "El gato" (relato singular en el catálogo que se analiza, destaca por no compartir, de forma superficial y genérica, cualidades semejantes a los demás textos), la acción ubicada en un espacio no rural: ocurre en una casona que ha pertenecido, desde tiempos de la independencia, a la clase militar, que es la representante del poder institucional. En este espacio no hay registro de animales salvajes, temibles o amenazantes, como el tigre del relato anterior, tampoco hay animales que representen un bien adquisitivo, la propiedad está determinada por un sistema de valores que no corresponde con la división primitiva del poder en la que el poseedor de tierras y animales de consumo tendrá un nivel superior en el escalafón social. Al campo corresponden animales que representan el campo: Salvaje, primitivo, instintivo, indomable, rudimentario.

Obsérvese ahora la descripción de un animal no rural: "mientras que en el rinconcito los círculos verdes de televisión, de semáforos verdes, de esmeraldas traspasadas de láser, de luciérnagas, no se escondían, ni se clausuraban y estaban allí fijos, como farolitos verdes que, en la calzada, la llovizna se hubiera olvidado apagar (p. 109). Los epítetos se construyen con sutiles símiles que remiten al desarrollo tecnológico de la urbe. Entre los atributos del gato está también su posicionamiento en el espacio cerrado, son espacios íntimos en los que los conflictos humanos no se comparten con otros congéneres, las colectividades no comparten las mismas necesidades. El colectivo pierde su poder actancial, al campo corresponde entonces, la unión de los seres en grupos determinados por el estatus; a la ciudad, la soledad, la intimidad, el individualismo, el desarrollo promovido por la tecnología, la modernidad.

Habría que corroborar la tesis que surge de la observación de estos relatos con otros textos de Changmarín, pero, por lo que se puede observar con la muestra de un cuento que no se apega a los tópicos reiterados en la prosa del autor: la instancia narrativa común, el autor implícito de todos los relatos, otorga 
distintas propiedades a ambos espacios de acción, por comparación y en oposición, el campo y la ciudad representarían polos dicotómicos que, en su configuración, determinan también a los personajes, es posible suponer, entonces que cada espacio y sus moradores serán antagónicos. La rudimentaria miseria está en el campo, el desarrollo tecnológico como bien de adquisición está en la ciudad. La miseria, tal como se entiende en esta muestra de textos, es un mal rural, los citadinos pertenecen a otro universo de acción, universo en que la miseria no es ni concebida, no, por lo menos, en los mismos términos. Entre ambos espacios no hay interés común. Las semejanzas entre la presentación de este mundo ficcional con la visión del autor real sobre el entorno panameño sólo pueden ser sugeridas.

De modo simbólico, el gato está vinculado con mundos místicos, tiene el poder de transitar entre el mundo terrenal y el inframundo, son misteriosos, silenciosos, guardianes de los secretos, también son hogareños, dependientes y receptores de afecto. Toda esta caracterización simbólica está contenida en el relato en el que un gato se aparece de forma misteriosa en la puerta de Lurda, con el tiempo, Lumbre, el felino, se convierte en el dador de satisfacciones físicas a la mujer solitaria. Tanto la puerta, señalada con reiteración, como las cualidades del gato, son recursos ficcionales que dan "verosimilitud" a la presentación de una historia secundaria que narra la trágica muerte de un oficial a manos de su superior por asuntos de amores, cuyo objeto de deseo es la mujer, Lurda, condenada a estar sola. La pasión se desborda en Lurda por un tiempo, hasta que el gato-hombre muere.

Los atributos de este relato remiten más bien a un estilo romántico, en el que lo fantasmagórico domina la acción, el tono nostálgico, el amor, son temáticas que se alejan del realismo que se expone en otros relatos, aun así, las estrategias narrativas conservan semejanzas, la más significativa para los intereses de esta aproximación es aquella que ya se ha mencionado: los animales determinan a los lugares y ambos inciden en las acciones realizadas por los personajes, pero también se mantiene el uso de epítetos que sirven para generar símiles, comparaciones que funcionan como puentes entre campos semánticos diferentes.

Con menos recurrencia que en otros textos, pero presente, a fin de cuentas, se observa la referencia a elementos naturales: la lluvia, la noche, los ojos del gato también se comparan con luciérnagas, árboles crecen en el patio de la mansión, entre otros. En una tercera observación se incluye la prosopopeya, la animación de elementos inanimados:

"Al fondo del patio maullaba la noche, o el gato.

-No es un gato -dijo ella- es la noche que llora, porque llueve" (p. 108).

Es llamativo que la prosopopeya no dote de capacidades humanas a los elementos afectados, sino de atributos propios de los animales. Otro ejemplo se lee en consecución con el anterior:

"porque afuera maullaba el gato o mugía la noche.

-La noche no podría ser -exclamaba." (p. 108)

La noche llora, muge, maúlla. Más adelante se lee: "El cuarto parecía un cielo oscurísimo con dos estrellas vivas, caídas en el rincón" (p. 110), en el que la noche es sólo noche, pero las estrellas imaginadas cobran vida en los ojos del gato, la prosopopeya se da en relación con la naturaleza. Este último ejemplo sirve para ver el uso del mundo natural en la construcción de juegos con el lenguaje que nutren el estilo narrativo del autor con un alto grado de liricidad, elemento común en todos los casos comentados. 
De mayor relevancia se destaca la relación entre los humanos, ejecutores de las acciones y los animales, en "El gato" el gato es, si bien un minino, es lo mismo un hombre. El juego metonímico destaca como recurso lírico que no se presenta en el lenguaje, pero sí de manera estructural, es decir, la mención no es clara en cuanto a la puntual señalización de las cualidades que comparten hombre y animal, pero en la historia es relevante que uno es otro. Aquí el animal no es un determinante de las acciones del hombre, es el hombre mismo.

El cuento que procede a "El gato", aunque no lleva por título el nombre de un animal y no ocupe un lugar preponderante para la lectura que se ha estado ejecutando, tampoco puede ser suspendido, "El hombre de Catival" escrito mucho tiempo antes (el primero es de 1971 y el segundo de 1954), narra la historia de un presidiario que hace un pacto con el diablo para convertirse en un ente volador y poder dejar la cárcel durante las noches y reunirse con su amada Margarita, a quien conoció una noche en la que ella misma, voladora, llegó a jalarle las cobijas.

El vuelo del hombre representa su libertad, el castigo del hombre es el cautiverio. El hombre trasmutado en ave es un suceso que interesa en la descripción del mundo animálico, la motivación del hombre para romper sus amarras morales y hacer un pacto con "el malino", están en el deseo carnal, en el deseo de mujer. Es tentadora la reflexión en torno al trato de la figura femenina y lo es también dilucidar en torno a la representación del amor, pero no hay tiempo para distracciones. En esta historia el hombre que quiere ser libre, amar en forma física y espiritual, precisa dejar su "cascarón": volar. Volar es un lugar común para la formulación figurada de la libertad, aunque no se espera que sea tal cual, que el hombre vuele, de la metáfora común se pasa al mundo ficticio en donde las fantasías son posibles, un ejemplo más del juego con técnicas que no son propias del realismo, pero que de alguna forma interesan aquí.

A diferencia de las otras narraciones, el lenguaje utilizado en este relato no está cargado con descripciones preciosistas, es muy llano y directo, en algunos momentos predomina el diálogo, por lo que la animalización del hombre colmado de deseos queda sólo como una anotación que formará parte de las conclusiones, pero no merece mayor atención en cuanto al análisis de niveles más sutiles que el de la historia, su relevancia se sustenta en el entendido de que la estrategia de animalización del ser es un rasgo que puede encontrar correlatos en otras narraciones.

\section{5. “Galápago en su concha”}

Por el contrario, "Galápago en su concha”, última narración en la que se presta atención y última narración de la antología, puede ser observada como caso representativo del mundo animálico como símbolo de marginación social. Esta narración cierra el conteo volviendo al inicio, el tema principal de la historia es el hambre, la misma clase de hambre que se representa en narraciones que se encuentran al margen de las que llevan por título un nombre de animal pero que, como parte del conjunto han sido mencionadas en las primeras anotaciones de este apartado analítico.

Aquí el galápago, la enorme tortuga no es el personaje principal sino el objeto sobre el que recaen las acciones, visto así es la narración de un hombre muerto de hambre que mitiga su carencia comiéndose una tortuga cocida en agua, una anécdota simple, de forma estricta, pero más allá del animal que podría formar parte de aquel segmento de animales que sirven para la vida humana; el relato cuenta la circunstancia de Zapato Bugué, un sujeto que decide cambiar y abrir sus horizontes. 
La cita que se transcribe a continuación es larga pero bastante esclarecedora en el desmontaje del entramado social:

Ahora Zapato Bugué había dejado a los pueblos, en busca de salarios y ya empezaba a civilizarse y a aprender las cosas de la gente "civile", como decía el alcalde. El alcalde de aquel pueblecito pegado a los estribos de la cordillera guaymí dijo, cuando el censo pasó por allá, lo siguiente:

-Bueno, por acá, gente hay poca, indios sí hay bastantes.

De modo que Zapato Bugué metido a mozo de las vaquerías, o peón de las cosechas de café, o machetero de los ingenios había aprendido las ventajas de los ciudadanos, de las gentes y tenía sus malas mañas de comer tres veces al día. Y ahora andaba por allí, metido en sí mismo con sus afilados ojos, las manos vacías; callado, sin solicitar, ni pedir; en el ejército de los desocupados; indígena con dignidad, timidez, orgullo y miedo. (p. 125)

En esta cita, el conflicto de Zapato inicia por aspirar a ser gente, ni siquiera gente "civile", solo gente; para ello precisa civilizarse, consecuente, cambia su oficio y adquiere nuevos hábitos como ese de comer tres veces al día. Sin embargo, su odisea fracasa después de los primeros intentos en los que realizó trabajos diversos, ya sin empleo ni labor no le queda nada más que su esencia que lo iguala con los de su condición, un sector social que no había sido referido en otros relatos, el de los indios: "Y tenía hambre porque no había podido colocarse en aquel pueblo y tampoco en el otro a donde fue, caminando, al estilo de la raza, a pie, y no sabía por qué en los pueblos no había trabajo ni nadie daba nada por nada”. (p. 126)

Los indios se colocan por debajo aun de los otros dos grupos representativos en la antología Faragual y otros relatos, según se indica, su carácter está delineado: dignidad, timidez, orgullo y miedo, pero no se explican las formas de ser o de manifestar esas cualidades frente a los otros, ninguno de estos atributos podría situarse en el extremo del bien o del mal. Cocidos aparte, comparten con los campesinos sólo el hambre.

Quizá sea aventurada la afirmación de que el galápago representa aquí una manera de ascender al indio a una categoría social mayor, si apelamos a las observaciones sobre otros animales de consumo humano a lo largo de las distintas historias, se ha dicho que los animales sobre la mesa son indicios de distanciamiento con la precariedad. Quien consume carnes no está en el extremo de la miseria. Zapato come carne, pero una carne robada y una carne de un animal atípico en la dieta humana. Este podría ser un buen ejemplo de ironía como recurso retórico. La ironía afecta el devenir lógico de los sucesos, pero su marca distintiva está en la reacción que provoca en quienes logran entenderla, cercana al sarcasmo, la intención es la de burlarse, ridiculizando, humillando o insultando directa o con forma matizada. El narrador en tercera persona mantiene, pese a mantener cierta distancia con los hechos una intención en la que el indio termina por ser posicionado en un sistema cruel de desprestigio.

El galápago es el animal de consumo de un hombre que debería adquirir los beneficios y la posición de la carne, pero viniendo de donde procede, en lugar de ascender, el hambriento cae en lo más profundo de la condición humana. Con "Galápago en su concha" se cierra el recorrido analítico que se había prometido, después de la observación cuidadosa es posible confirmar que el mundo animálico en la narrativa de Changmarín es un rasgo distintivo, la fauna constituye un sistema semiótico de representaciones mediante el cual se entretejen diferentes niveles narrativos, por ello, por su variedad de formas y significados 
y la recurrencia de su aparición en la mayor parte de los textos dispuestos en Faragual y otros cuentos el animal puede ser un significante imprescindible en la representación simbólica de la marginación social.

\section{Conclusiones}

La prosa de Changmarín da primacía a una intención descriptiva que transparenta la realidad social en un entorno rural: se detiene en la observación cuidadosa de la flora y la fauna de Panamá, en la observación concienzuda de los roles sociales de los habitantes menos favorecidos de distintas regiones del país; en su prosa, se le confiere a la naturaleza el poder de incidir sobre los hombres, sus acciones, sus decisiones: el canto de las aves, el caudal de una fuente de agua, las huellas de una bestia, el tránsito del sol, son potenciales mediadores de las actos humanos. Los personajes, aunque prototípicos, no dejan de ser complejos, redondos: dudan, padecen, sufren, se regocijan. Los adjetivos son limpios, transparentes, pero no simples. Para lograr esas cualidades, el uso de recursos retóricos se convierte en herramientas descriptivas, bajo ese crisol, la retórica se torna compleja para el ojo analítico pero ineludible si se persigue desentrañar las cualidades estilísticas o, en otro nivel de análisis, los contenidos discursivos.

El realismo sirvió como modelo estético de expresión, pero también ha tenido, hasta el día de hoy, una importante función política, ideológica y social. Las realidades que alimentan la creación literaria de los países de la América hispánica han sido complejas, contradictorias, violentas en la mayoría de los casos; el entramado social y el relato de la construcción de las naciones que la conforman: su devenir histórico, ha dotado a la creación artística en general y a la literatura en particular de una serie de rasgos característicos que además de marcar la estética predominante; dibujan, ilustran, acusan, protestan, sensibilizan y denuncian el estado general de injusticia que corrompe, desde sus bases, a las sociedades.

En la era de la proclama de los derechos humanos, los escritores de Latinoamérica usaron sus plumas para confrontar el anhelo de una sociedad idealizada con sus propios entornos, la tendencia no fue exclusiva de una entidad, hay representantes de esta forma particular de realismo en cada una de las naciones, la obra de Changmarín es, en este contexto, uno de los ejemplos que se debe destacar en la expresión realista panameña.

Después de la ubicación del autor en una corriente literaria, fue preciso atender a sus particularidades, observar los recursos que autentican a la voz narrativa como una voz singular. En esta ocasión se seleccionó la antología de relatos Faragual y otros cuentos por considerarla una muestra representativa de la producción narrativa del autor, puesto que congrega relatos elaborados en distintos momentos, permite atender la variable diacrónica y facilita la determinación de una tesis que atiende un tópico transversal.

En un primer acercamiento fue posible observar a los animales como entes que, de manera recurrente, contribuyen a la construcción del mundo ficticio que recrea el autor. También destacó la marginación social como tema continuo que vincula la realidad social con la realidad ficcional. Para lograr el correlato entre el mundo animal y la marginación se realizó un análisis que comprendía tanto la función de los animales con relación a la narración de los hechos y al desarrollo de los conflictos, así como a la forma particular de representar a dichos seres, es decir, a los recursos estilísticos, para lo cual fue necesario observar tanto el léxico como los recursos retóricos en actuación. 
En síntesis, en cuanto a la función que desempeñan en la estructura narrativa destaca la representación de los animales como actores principales de la acción, son constantes los casos en los que los animales son determinantes en la acción narrativa: En "El tigre", "La vaca", "El gato" o "El diario de la yegua del alcalde", el autor utiliza a los animales como protagonistas, ya sea como sujetos de la acción o como objetos de la misma, alrededor de ellos, los personajes humanos serán oponentes o ayudantes.

Cuando los animales contribuyen a la determinación del espacio, develan las cualidades ya sea del campo o de la ciudad, lugares en los que se desarrollan las tramas de Faragual y otros cuentos. El entramado social, por su parte, también estará determinado por las cualidades y potencialidades espaciales, en el campo habrá una organización social distinta a la de las ciudades, no son polos opuestos explícitamente, sino entornos independientes con estructuras civiles también diferentes; descolocar a un sujeto de su espacio de acción puede ser el motivo de un conflicto, como en "Galápago en su concha" en el que un indio no encuentra cabida en la jerarquía social porque su procedencia no es propia del orden citadino, sin posición, queda relegado al estrato más bajo de la jerarquía, inclusive, puede decirse que se le coloca fuera de ella.

El personaje colectivo que ostenta el poder económico, de impartición de justicia, celestial o espiritual, está representado por las instituciones sociales: iglesia, gobierno y sociedad. A este grupo se le correlaciona con los animales de consumo, y sus atributos serán por ejemplo, la fiereza, la bravura, el coraje, sienten odio y desprecio por los otros humanos y empatía por los animales que ayudan a incrementar su posición jerárquica. Las amenazas no son, para este grupo, las acciones que pudieran venir de la contraparte, es decir, el colectivo dicotómico no es un oponente, sus amenazas provienen del temor a la pérdida de su estatus.

El colectivo opuesto está representado por el campesinado, personas sometidas al sistema opresor, son abusados, discriminados, desposeídos, hambrientos, infortunados, pero están dotados de cualidades morales que sus oponentes carecen, son razonables, sensibles, empáticos y tienden a participar comunitariamente. Su amenaza principal proviene del hombre que anhela su bien, la tierra. En la tierra se encuentra otro indicio diferenciador, para el campesino la tierra es proveedora de alimento: dadora de vida; para sus oponentes la tierra pertenece al ganado, da vida a los animales que representan estatus, las visiones son distintas pero en su representación práctica animales y campesinos están en el mismo rango.

Marginar es, según la Real Academia Española, la acción de "poner o dejar a una persona o grupo en condiciones sociales, políticas o legales de inferioridad" (RAE, web), se entiende que el acto de marginar sólo puede ser ejecutado por quien ostenta el poder; en los cuentos de Changmarín, tratándose de campesinos e indígenas, no hay impartición de justicia, las instancias por el contrario favorecen a los poderosos, explícitamente esos son los casos de Tranquilino en "El tigre”, también se manifiesta en "Faragual", o en "El diario de la Yegua del alcalde”, último caso en el que la estadía del animal afuera de la iglesia no le sirve de nada, la fe es un recurso esperanzador siempre y cuando no intervenga la iglesia, la carencia y el hambre son signos de marginación cuando un sector tiene la capacidad de proveer bienestar pero no lo hace.

La marginación en Faragual y otros cuentos está ligada a la injusticia y al abuso, no sólo es que "se deje" en un estado de inferioridad, sino que, los portadores del poder actúan en su propio beneficio, atendiendo a sus intereses, violentando al grupo en desventaja. La violencia no sólo se da por omisión, se produce mediante el abuso de poder físico, psicológico, legal, judicial, social, etcétera.

El tema al que circunscriben estas líneas debe conjuntar, por un lado, la marginación, por el otro, remite al mundo animal; después del largo recorrido que ha atendido pormenores para explorar los vértices de confluencia entre un universo y el otro, es posible cerrar la exposición afirmando que, la 
- Revista de Ciencias Sociales y Humanidades. ISSN-P: 0188-9834 ISSN-E:2395-8669.

marginación, aunque ejecutada por personajes humanos, no alcanzaría un nivel de representación significativo y transversal de no ser por la fauna, los animales, inmersos en distintos niveles discursivos son, en la prosa de Changmarín, símbolos del poder, de la clase social, determinan los atributos de las personas, de los colectivos; en conjunto, el mundo animálico en Faragual y otros cuentos, es un ordenador social y un determinante en su división desigual.

\section{Referencias}

Bajtín, M. (1989). Teoría y estética de la novela. Trabajos de investigación. Taurus Changmarín, F. (1978). Faragual y otros cuentos. Impresora Educativa.

Chevalier, J. y Gheerbrant, A. (1993). Diccionario de símbolos. Herder.

Estrada, A., Pérez, L. (1983). Textos Literarios II. Tercer semestre. SEP. Preparatoria abierta.

Genette, G. (2001). Umbrales. Siglo XXI.

Puccini, D. y Yurkievich, S. (2010). Historia de la cultura literaria en Hispanoamérica. Fondo de Cultura Económica.

Real Academia Española. Diccionario de la lengua española, 23. ${ }^{a}$ ed., [versión 23.3 en línea]. https://dle. rae.es [Consultado el 28 de agosto de 2020]. 